\title{
Histórias de médicos: vida de trabalho entre a prática liberal e a medicina tecnológica
}

\author{
Stories of physicians: work lives in the \\ transition from liberal professional practice \\ to technological medicine
}

$\mathrm{O}$ s depoimentos a seguir são produto de um estudo realizado no final da década de 1980 e suscitado pelas mudanças na medicina que eu mesma, médica da década de 1970, experimentava: a ultra-especialização médica e o assalariamento da profissão. Mas por ser também pesquisadora interessada na prática médica, diante da espantosa disparidade de imagens e expectativas dos médicos (é bem verdade que mais relativa ao assalariamento que à especialização), considerei fatos dignos de serem estudados: ${ }^{1}$ a mudança da medicina e até a dificuldade dos profissionais de lidarem, em seu ideário, com ritmo tão intenso de transformações.

Meu primeiro caminho foi buscar a história registrada. Na ausência desta, procurei obtê-la através dos relatos dos próprios médicos. A princípio, elegi certos luminares: professores catedráticos, introdutores de técnicas, instrumentos e especialidades na medicina etc. Contudo, nas primeiras entrevistas, percebi que aquilo que mais me interessava, o dia-a-dia da prática médica, estava sempre ausente dos relatos obtidos. Minhas perguntas, em realidade, eram: como havia sido o cotidiano do trabalho no exercício da medicina liberal? E como se transformara tanto?

Voltei-me, então, para personagens dessa história inseridos na vida comum da profissão, para buscar depoimentos com a qualidade de testemunhos pessoais. Apoiada na técnica de entrevistas com uso de gravador e buscando recuperar histórias de vida, enfatizando a vida profissional, colhi depoimentos de médicos que se formaram entre 1930 e 1955. Ao registrar as narrativas, apenas dois dos nove médicos entrevistados estavam aposentados. Seus testemunhos revelam o exercício profissional que se iniciou em tempos de prática liberal e se atualizou no que chamei de medicina tecnológica, para dar ênfase ao aspecto tecnicista do trabalho que se empresariou, especializou e

\footnotetext{
1 Minha tese de doutorado, Medicina liberal e incorporação de tecnologia: as transformações históricas da autonomia profissional dos médicos em São Paulo, defendida em 1989, foi publicada sob o título O médico e seu trabalho. Limites da liberdade (São Paulo, Hucitec, 1993).
} 
rompeu com certa homogeneidade de conformação técnica e mercantil. Esse tecnicismo, que se instaura a partir da década de 1960 e se firma nas de 1970 e 1980, parece estar cedendo lugar a outro movimento de transformações e ruptura tecnológica. ${ }^{2}$ Mas essa já é outra história....

Embora os nove depoimentos fossem tomados como conjunto representativo de um mesmo percurso, publicamos agora, reeditados e sintetizados, apenas dois testemunhos: os da dra. Emília, formada em 1931, e do dr. Carlos, formado em 1953. Foram escolhidos porque representam situações diacronicamente extremas e mostram, por isso, as diferenças internas ao período tomado, além de evidenciarem, como toda história de vida, suas singularidades nos planos pessoal e profissional. Também mostram os aspectos comuns que fazem dessas histórias individuais a expressão de um tempo coletivo. Agindo em consonância com ele, a dra. Emília e o dr. Carlos, por seus atos e escolhas, participaram da construção da medicina tecnológica e da renovação da prática profissional, incorporando a ela a especialização e os equipamentos. Ajustaram suas práticas de consultório às novas formas mercantis: associações de profissionais formando clínicas ambulatoriais; interiorização do consultório no hospital; e credenciamento com empresas médicas na captação da clientela. Ao mesmo tempo, buscaram preservar aspectos do passado, características da prática liberal, como o tempo prolongado de conversa, a apurada anamnese, determinada atenção e disponibilidade para com o 'seu' paciente, e uma certa individualização no interior de suas clientelas institucionalizadas. Assim, conservaram para si mesmos determinada margem de liberdade no trabalho, na esfera da produção e da comercialização.

A dra. Emília e o dr. Carlos pertencem àquele conjunto de médicos que viveu a travessia de um tempo a outro, muito diverso: do chamado domiciliar à medicina do pronto-socorro; do médico-herói ao medicamento-herói; do médico de vocação e talento (arte de curar) à medicina de precisão (ciência de curar); da relação interpessoal médico-paciente ao contrato jurídico dos convênios; da confiança no 'meu' médico à confiança na tecnologia 'do' hospital; da medicina de bairro à medicina de grupos e do seguro-saúde; da medicina masculina e centrada no médico à presença progressiva da equipe de trabalho e das mulheres na profissão.

Preservar, com alguns custos profissionais, o consultório particular, à imagem de um 'território livre', constituiu o ponto crítico de suas trajetórias. Pareceu-lhes que, nesse território, por um grande esforço pessoal, apesar da incorporação de mudanças técnico-científicas, administrativas e mercantis, conseguiram resguardar uma medicina da mesma qualidade da que idealizavam como boa prática liberal. E enquanto separavam esse núcleo, abrigando nele um conjunto destacado de procedimentos, criavam e aprofundavam alterações no trabalho liberal. Assim, supondo que preservavam, com seus ajustes, o caráter 'universal' da prática e sua 'essência' de autonomia, constituíamse, de fato, em sujeitos de uma história caracterizada por profunda reconstrução de atos e concepções. Seus movimentos, que os levaram a se inserir nas transformações mais gerais da medicina, são representados por eles como se fossem 'movimentos de resistência'. Não se vêem inseridos em processos de mudança, e externam o sentimento de que perderam o tempo que foi verdadeiramente o 'seu'. Para lidar com esse

\footnotetext{
2 Desde agosto de 1996, venho colhendo novos depoimentos, agora de médicos formados entre 1980 a 1985, que têm confirmado a suspeita de que um novo modelo médico está se configurando.
} 
paradoxo, enquanto se atualizavam na profissão, iam cunhando a imagem de que, por estratégias pessoais, conseguiam se manter em um modelo independente, num 'outro tempo' incrustado no tempo presente.

Que suas narrativas nos mostrem esses tempos.

Lilia Blima Schraiber

Profa. do Departamento de Medicina Preventiva da Faculdade de Medicina da USP Av. Dr. Arnaldo, 455, $2^{\underline{0}}$ andar. 05021-001 São Paulo — SP Brasil e-mail: liliabli@usp.br

\section{“É uma profissão para homens, minha filha! Precisa muito estudo e muita coragem. ..."}

\section{Dr. Emília}

Nasci em 21 de outubro de 1902, em Rio Claro, e logo me mudei para São Paulo. Devo à minha família o que eu sou e fui, e a ela rendo, nesse momento, a minha gratidão. Meus pais eram italianos. Mamãe chegou ao Brasil com cinco anos. Ignoro quando papai veio, mas acho que ainda era criança. Faleceu muito cedo, aos 32 anos, provavelmente vítima de moléstia cardíaca. Chamavase Anselmo, este comerciante forte! Eu vim pequena para São Paulo, com um ano ou pouco menos. E, aqui, penso que fiquei morando no Brás.

Decidi fazer o curso de dentista porque mamãe queria que a gente tivesse uma profissão. Para ser auto-suficiente... Assim que me formei, tive gabinete dentário na rua Piratininga, numa casa de dois lances, e ali cliniquei. Meu gabinete foi todo importado! Meu padrasto mandou vir da Alemanha. Ele não era uma pessoa de posses. Era... mais ou menos. Mas naquele tempo tudo rendia, porque tudo era dentro de casa! Tudo era feito em família...

Quando fiz odontologia, já queria ser médica, e quando entrei na faculdade de medicina, passei a clínica dentária para minha irmã. Comuniquei a decisão à mamãe, e ela disse: "É uma profissão para homens, minha filha! Precisa muito estudo e muita coragem. E você é tão fraquinha..." Mas, como minha mãe, eu era persistente, puxei por ela!

Quando cursávamos anatomia, o professor era o Bovero. Era um grande professor contratado no estrangeiro. Então ele dizia: "Na semana que vem, as moças não vêm à aula, porque nós vamos dar órgãos genitais masculinos." O Flamínio Fávero depois dizia: "Na semana que vem, as moças não vêm à aula, porque nós vamos dar moléstias... desvios da sexualidade." E naquela semana nós não tínhamos aula, porque não era para as moças assistirem às aulas! Hoje em dia, todo mundo dá risada... Quer dizer que médica mulher não podia ser médica de urologia, não 
“A profissão médica não é profissão, é uma vocação, pelo menos naquele tempo era. Não era assalariamento, era um sacerdócio ...” podia ser médica de homem? Não! E não podia conhecer esta grande variedade de distúrbios sexuais. Mas depois, na prática, a mulher ia pedir as coisas de relações ano-retais e tal, e apanhávamos, assim, porque não tínhamos tido a aula. Para começar, médica, mesmo clínica geral, não examinava homem. Aliás, eu acho que nem precisa! Hoje tem quem trate do homem! Homem é sempre homem e mulher é sempre mulher... não dá certo! Em geral, as médicas da minha época faziam pediatria ou clínica geral, mais ligada à parte de senhoras, mesmo. Hoje se vê doutora famosa aí que faz muito bem moléstias ano-retais... faz proctologia, e faz muito bem.

Pensei em fazer ginecologia e obstetrícia, e me dirigi para cirurgia no quarto ano. Naquele tempo, nós é que dávamos a anestesia. Era dada pelo estudante. Então, o operador dizia: "Olha, o sangue está escuro. Olha, o sangue está claro. Diminui a anestesia!" Começamos com o clorofórmio. Um pouco tomava na máscara o doente, outro pouco nós... Depois é que vieram esses progressos da anestesia. Quem se dirigia para a cirurgia, era assim. Eu desde o quarto ano, porque todos, em geral, se inclinavam para as especialidades. Continuavam com as matérias básicas, mas se inclinavam para aquilo que queriam seguir. Eu achei, por exemplo, que a clínica geral era uma bela especialidade, mas não se adaptava muito a meu temperamento, de imediatista, prática e objetiva. Achei que era difícil ser um bom clínico. E o bom clínico é o grande médico de hoje... é o grande médico de amanhã e sempre!

Precisava estudar muito, e naquele tempo os recursos eram muito pequenos e os resultados não eram palpáveis, por assim dizer. A área cirúrgica era mais... mais objetiva. Fui escolhendo essa área também por outra coisa. Primeiro, por questão do meu temperamento. Eu tinha saúde, tenho raciocínio pronto, tenho uma determinação imediata, e a especialidade exige raciocínio, saúde. Hoje já é um pouco diferente, mas naquele tempo precisava ter saúde para fazer obstetrícia. Levantar à noite, fazer um parto, por exemplo, às duas horas da manhã, depois às cinco horas, e outra vez ao meio-dia. Agora, não! Resolvem-se mais rapidamente as coisas. A profissão médica não é profissão, é uma vocação, pelo menos naquele tempo era. Não era assalariamento, era um sacerdócio, por assim dizer. Íamos atender longe, de graça, deixando até dinheiro para o cliente. Não havia nenhuma dessas organizações que existem hoje, e que tanto facilitam a vida do médico. Chama-se o pronto-socorro, e o pronto-socorro vai levando o paciente, depois o médico vai onde o paciente foi. Isto despersonificou o médico. O doente já não faz questão do seu médico. Vai ao hospital e aceita o que está de plantão. No meu tempo, ficava-se escravo, mesmo. Porque se perdêssemos a hora do parto, se a paciente não fosse atendida... Ah! Aquilo era uma coisa séria! O paciente fazia a sua propaganda. 
"As pacientes não queriam ir para o hospital. No parto, não! ... por medo das infecções. ... tínhamos um colosso de mulheres, coitadas, que morriam de infecção puerperal naquele tempo..."
A Cruz Azul, uma instituição que dava assistência às famílias dos soldados, praças e oficiais da força pública, foi a primeira que teve assistência ao parto domiciliar pago pela organização. Os partos eram feitos a domićlio por comadronas. Não havia muitas pessoas formadas, porque foi a Maternidade São Paulo que fez a escola de parteiras, por volta de 1913. De maneira que eram umas pessoas adaptadas, por assim dizer, ao serviço, e controladas até certo ponto por médicos, mas não eram formadas. Então a Cruz Azul teve o parto domiciliar: a parteira chamava por alguma coisa e nós nos atrevíamos, naquele tempo, a fazer algumas intervenções em casa! Já viu isto? E não tínhamos infecções! Por exemplo, a parteira chamava numa hora. Depois, o parto se modificava e, quando chegava a hora, as condições eram diferentes. Resolvíamos os problemas com pequenas intervenções que eram feitas a domicílio. Só se tivesse uma intervenção maior, as pacientes eram removidas para o hospital. As próprias pacientes não queriam ir para o hospital. No parto, não! Ninguém queria o hospital por medo das infecções. Porque tínhamos um colosso de mulheres, coitadas, que morriam de infecção puerperal naquele tempo...

A Segunda Guerra Mundial trouxe algum benefício, o advento das sulfas e, em seguida, a penicilina de Fleming, que foi um grande recurso para nós. Antes da descoberta dele, aliás, até 1944, tínhamos muito essas venéreas sifilíticas. Eu, em 1944, numa entrevista ao Diário da Noite, disse que achava que quando o cidadão casasse, devia levar, junto com a certidão de nascimento, um atestado médico. Por causa da coisa horrorosa que se via em mulheres recém-casadas, moléstias venéreo-sifilíticas em evolução. Se enchendo de anexites. Era assim, como presente de lua-demel! De maneira que isso era uma coisa que impressionava grandemente mesmo! Naquele tempo, para sífilis, antes da penicilina, só tínhamos bismuto, mercuriais, essas coisas. E, na clínica particular, pedir exame para sífilis era feio. De maneira que, quando eu precisava pedir um exame, telefonava para o laboratório e dizia: "Olha, o exame de sangue que eu quero é para Wasserman." Então vinham quatro cruzes, e a família ficava zangada: "Isso não pode ser!" Mas só depois que eu tinha as quatro cruzes é que podia tratar uma mulher. Naquele tempo, se via a sífilis nervosa, a tabes, essas coisas que não são mais vistas.

Foi em 1944 que a penicilina entrou a todo vapor. Mais ou menos em 1939 fizeram-se as primeiras observações, e até havia pouca penicilina. Quando se começava um tratamento, não tinha penicilina para continuar. Em 1944, a penicilina foi posta no mercado de vez. Aí usou-se à grande, as infecções puerperais, os panarícios, as erisipelas e aquelas coisas que nós tínhamos sumiram do mapa.

As moléstias que mais me calaram foram as venéreas. Sífilis e moléstias venéreas eram as afecções que enchiam os consultórios. 
"Sífilis e moléstias venéreas eram as afecções que enchiam os consultórios. Depois, os corrimentos, específicos ou não, para os quais nós, hoje, temos medicações ricas."
Depois, os corrimentos, específicos ou não, para os quais nós, hoje, temos medicações ricas. Em cada setor, a medicação para o tipo de doença. Até a profilaxia, que se faz com o papanicolau obrigatório, é uma grande coisa. Já se pode falar em cura de câncer em estágio um, estágio dois. Antigamente, só se pegava em estágio quatro!

Nem todas as infecções eram tratadas igualmente com a penicilina. Dependia muito. Houve um pouco de abuso, mas ela foi heróica, foi uma medicação heróica! Quando entrou, foi divulgada rapidamente. Primeiro era aquela de três em três horas. Tinha doente que eu ia na casa - porque a clínica era domiciliar - fazer injeção, e depois de três horas voltava para fazer outra injeção, depois outra. O farmacêutico não queria fazer, e nós, que éramos médicos de vocação, queríamos ver o paciente bom. Então íamos! A penicilina resolveu em grande parte as infecções ginecológicas. Nos abortos provocados, foi de grande valia. E isso, até certo ponto, lá no ambulatório da Cruz Azul, mudou muito o perfil dos doentes. Passaram a aparecer as malformações, os tumores e afecções diferentes. Veio a era dos tumores, das disfunções hormonais.

Eu mesma tive uma paciente, muitos anos atrás, era uma mulher que teve seu primeiro filho. Foi cesariana. Tinha 46 anos, e o marido, sessenta. Tinha ido ao meu consultório porque estava na menopausa. E quando a examinei, eu disse: "A senhora está grávida!" Ela disse: "Não! Não pode ser, porque eu tratei toda a minha vida e nunca tive filhos!" Eu insisti: "Bom, a senhora vai esperar e ele vai começar a mexer. A senhora está grávida." Quando fizemos a cesariana, ainda não tínhamos os antibióticos nem as sulfas. Os quadros abdominais posteriores a todo tipo de intervenção eram paralisias intestinais, era muito mórbido o pósoperatório. Então veio a sulfa, o anaseptil peritoneal e o anaseptil líquido. Ela foi operada e teve alta. Naquele tempo, a alta não era assim, dois dias depois da operação vai embora. Não! Esperavam-se seis, sete dias. Lembro que era interna do hospital e, quando fui dar alta, passei e vi outra mulher que tinha o sono da doença meningiana: "Puxa! Essa mulher está com alta?!" Entrei e pus o termômetro: estava com $40^{\circ}$ de temperatura! Sentei na cama, peguei uma agulha e puncionei a raque: deu líquido opalescente. Imediatamente, injetei duas ampolas de anaseptil - que nunca tinha usado - na veia. Os dedos dela ficaram escuros, sabe, ela teve uma reação tremenda! Mas eu já tinha tirado o líquido para exame, que deu meningite pneumocócica, porque ela tinha tido uma pneumonia. Essa mulher ficou boa. E o prof. Meira, quando viu o resultado, disse: "Nunca vi ficar boa de meningite pneumocócica." Foi a primeira vez que usei o anaseptil, e o usei intra-raquidianamente! Essas eram coisas que fazíamos. 


"Eu tinha
facilidade, pelo
fato de os
maridos
quererem que as
mulheres fossem
examinadas por
outra mulher. E
elas se sentiam
mais à vontade.
Com aquele
negócio do pudor,
de vergonha de
exames e tudo,
preferiam uma
mulher."

Tudo tinha que ser rápido! A operação, por exemplo, não podia demorar porque não tínhamos anestesia que desse alguma segurança. Os recursos que existem hoje... é uma beleza! O cidadão trabalha horas, calmo, sereno...

Nessa época, eu acompanhava as mulheres no ambulatório e, depois, se precisasse operar, eu operava! Eu era assistente do serviço, e operava com o chefe ou, às vezes, sozinha. Quando comecei, o cidadão dizia: "Você vai tratar com uma mulher?!! Hum..." E a paciente: "Olha, mas ela opera! Eu vi! Vou tratar com ela, sim, porque ela opera!" O fato de operar era uma coisa de que as pessoas gostavam. Era importante. A pessoa dizia assim: "Ela, então, é estudada, dá assistência ao parto, faz cesariana..." Isso dava um prestígio... dizer que se trabalhava como homem porque a idéia de cirurgia era de homem trabalhando. Eu me lembro uma vez que fui atender a um doente de uma família importante, uma casa muito linda, muito grande... Entrei e, sabe como é, tinha aquela postura de médico de outrora; me vestia reservadamente. Naquele tempo, toda a família ficava na sala de visitas para esperar o doutor. Cheguei, cumprimentei e fui entrando. Mas não estendi a mão, porque não estendia a mão para ninguém. Não é por nada, mas tem pessoas que gostam de segurar a mãozinha da gente... Naturalmente, o chefe da casa ficou magoado, mas depois fui médica da família inteira, durante toda minha vida profissional.

Tive consultório também. O primeiro foi na rua Benjamin Constant, com o Salles Gomes. Eu me formei e fui procurar consultório para dar consultas. Não podia gastar muito. E o Salles Gomes me disse: "Olha, se quiser vir, você aluga a sala." Depois de uns dois anos, transferi meu consultório para a Senador Feijó, onde fiquei todo o tempo. Fazia ginecologia e obstetrícia. Ele era um grande especialista, dirigiu o serviço de lepra em São Paulo. Lá no consultório só dividia o espaço, mas eu não tinha nada a ver com o serviço dele. Eu sempre trabalhei sozinha! Sempre sozinha...

Algumas vezes tinha colega novo que queria começar a clínica, então alugava, por uns tempos, o consultório ao lado. Mas, sabe, era pessoal novo que pensava que a clínica ia logo e acabava saindo. Porque era difícil a clínica. Eu tinha facilidade, pelo fato de os maridos quererem que as mulheres fossem examinadas por outra mulher. E elas se sentiam mais à vontade. Com aquele negócio do pudor, de vergonha de exames e tudo, preferiam uma mulher. Quer dizer que o pessoal, assim, da classe mais abastada não ficava com receio. Bem, nos primeiros tempos, ficava... mas foram obrigadas, pela vergonha da doença, o pudor... e por causa dos maridos... As mulheres de classe mais baixa já iam mais aos médicos de bairro. Não se abalavam até a cidade.

De maneira que eu não tive dificuldade em ter clínica. Foi devagar. Com o Salles Gomes, a clientela foi chegando. E quando 
mudei de consultório, os pacientes acompanharam. Era ali pertinho! Porque, antigamente, a clínica era no Centro da cidade. Era na Conselheiro Crispiniano, Senador Feijó, aquela zona ali. Depois, naturalmente, essa zona ficou de lado e os consultórios foram para outro lugar. Alguns faziam clínica de bairro. Poucos! Eram pessoas que talvez não pudessem ter consultório. Porque a clínica de bairro era clínica de tudo. Agora, no Centro, não! Eram só médicos especializados. Tinha o Rubião Meira, quatro ou cinco professores, todos ali. Era zona médica mesmo, que depois foi se degradando...

Assim que me formei, montei o consultório. E assim que me formei, comprei também um automóvel. Eu disse: "Preciso atender os meus chamados." Então comprei um Chrysler 28. Naquele tempo, poucos andavam de automóvel. Então diziam: "Olha o carro da doutora!" Eu gostava de dirigir. Num serviço, por exemplo, ia à noite, de madrugada, a qualquer lugar. Nunca tive medo. Mas quando voltava, às vezes eu dizia: Que coragem, Emília! Se meter nesse mato, na Parada Inglesa! Meu Deus! Às vezes eu dizia para o fulano: "Olha, agora precisa comprar remédio para sua senhora. O senhor vai buscar." Ele dizia: "Eu vou buscar amanhã na farmácia." Eu falava: "Não, o senhor vai agora, porque é para tomar já." Isso era para ele ir comigo até o ponto onde eu tinha medo de voltar. Porque, na hora, na vontade de ser útil e fazer alguma coisa, não se pensa. Então ia lá para Parada Inglesa, para Chora Menino, há cinqüenta anos, para esses lugares que nem hoje se tem coragem de ir... E ia sempre contente!

Naquela época o médico ganhava pouco! Mas não funcionava muito o ganho. O médico era sempre igual, o cliente pagando ou não pagando, sabe? Talvez as necessidades econômicas daquele tempo fossem satisfeitas com pouco. E o médico não precisava ter o alto padrão que hoje ele deseja ter diante da sociedade, mas que não tem diante da coletividade. Porque ontem, quando ia ver pacientes, tinha consideração. Eles me tratavam com uma deferência que, hoje, não têm mais. O médico, hoje, é um qualquer com quem o paciente vai fazer a consulta. Ganha o seu dinheiro como qualquer... qualquer trabalhador. É um assalariado! Antes ele dizia "o honorário"; hoje, "eu pago". A relação com o paciente ficou mais fria, mais impessoal. De maneira que se comercializou, inclusive, a vida do paciente. Tudo se transformou! Há hospitais, por exemplo, que apesar de o aborto não ser permitido, continuam um aborto provocado, e pronto, acabou! Isso é proibido por lei. É comércio! Na sala de operação, o médico retalha e tal, e vai andando. Então foi aos poucos perdendo aquela característica de médico...

Para os médicos, eu gostaria, então, de deixar registrado que seja mais médico! Que pense que cada doente poderia ser seu familiar, que estivesse consultando o 'seu' médico! Também queria 
que fosse registrado que é preciso exaltar o médico da medicina preventiva, o sanitarista, porque é a medicina de amanhã. Veja a varíola, erradicada, a poliomielite... que beleza! Quero que no meu depoimento conste um hino ao sanitarista! Em resumo, deixo registrada essa mensagem aos profissionais de hoje. Primeiro, ao atenderem o paciente, tenham presente um ente querido. Só assim ressurgirá a figura venerável do médico de outrora. Segundo, o clínico é um grande médico, pouco valorizado atualmente. É o primeiro especialista que o paciente consulta. Terceiro, enfatizo o médico da saúde pública, que tanto dá à medicina de hoje e do amanhã. Quarto: o médico é algo mais que um assalariado, porque ele trata do material mais nobre, o ser humano.

\section{Dr. Carlos}

Nasci na capital de São Paulo, no Centro da cidade, onde hoje é o começo da avenida 23 de Maio, na rua Asdrúbal do Nascimento, que está incorporada ao começo dessa avenida. Nasci em 19 de junho de 1927. Era filho de uma família simples. Meu pai era autoditada, interessado em leitura. Gostava muito de estudar, mas só tinha feito - no antigo Ginásio do Estado — até o primeiro ou segundo ano. Aí ele largou e foi trabalhar, para sustentar os pais. Morei sempre naquela região do Centro da cidade porque meu pai trabalhava na cidade. Naquela época era fácil!

Quando completei a escola primária tinha dez, onze anos. Naquela época, havia muita preocupação com a saúde (porque muito estudo prejudicava), então meus pais resolveram que, ao invés de eu ir direto para o ginásio, devia fazer um ano de admissão. Depois comecei o ginásio. Entrei no Colégio AngloLatino - de 1945 a 1947. Tinha de tudo! Os professores eram alunos da Poli, Medicina, Química, outros eram estudantes da Faculdade de Filosofia da Universidade São Paulo (USP). Meu professor de biologia foi um médico formado pela USP em 1940! Então, aí, eu estava decidido a fazer medicina.

Naquela época, não se tinha outra orientação. Escolhia-se quase que... a olho, vamos dizer assim. Tenho a impressão de que foi influência de meu pai. Nós conhecíamos advogados e políticos, porque eles freqüentavam muito a firma de meu pai, que era muito importante. E também médicos. Conheci vários. Um deles faleceu em 1941, o dr. Nacarato. Tenho a impressão de que esse homem nunca cobrou uma consulta de ninguém! Era amigo de todo mundo! Quem necessitasse ia procurar o dr. Nacarato. Ele estava sempre às ordens. Eu me recordo, por exemplo, que em 1940 fiz uma asneira. Caí com o braço esquerdo para trás do corpo e fraturei o terço superior do úmero. Então, fui para casa 


“...o médico era
uma pessoa
aureolada, muito
diferenciada!
Eram pessoas que
tinham uma
influência muito
grande, mais que
as outras
profissões,
inegavelmente!
Alguns eram
conselheiros de
família. A pessoa
ia ao consultório
pedir opiniões
para tomar
decisões, até
sobre casamento
de filhos!”

“...o médico era

uma pessoa aureolada, muito

diferenciada!

Eram pessoas que

tinham uma

influência muito

grande, mais que

as outras

profissões, inegavelmente!

conselheiros de
família. A pessoa
ia ao consultório
pedir opiniões
para tomar
decisões, até
sobre casamento
de filhos!”

todo dolorido, e fomos parar nesse dr. Nacarato e, por indicação dele, com uma cartinha, fomos tirar raio X, na rua Xavier de Toledo, num aparelho moderníssimo, com um médico italiano, o dr. Vicentova. Não se pagou nada, nem a ele, nem ao raio $\mathrm{X}$, porque foi a pedido do outro. Daí me levaram para o Hospital Matarazzo — na época era Umberto Primo - e lá outro médico me imobilizou. Era amigo de meu pai. Meu pai mandava cigarros para ele porque trabalhava na fábrica de cigarros Sudan - já existia, na época, a Souza Cruz, que era estrangeira, e a Sudan era a maior fábrica nacional - e quando precisava ele atendia minha avó, outro dia atendia não sei quem, e assim por diante. Então tinha esse espírito... Outros médicos também... Mas não creio que tivessem influenciado minha decisão de estudar medicina.

É verdade que os médicos, naquela época, eram pessoas, assim, ilustres. Muito considerados! A consulta era feita da seguinte maneira. Raras pessoas tinham carro, mesmo médicos. Então, ao ser chamado, o médico ia atender a domicílio - o famoso chamado domiciliar, a que hoje todo mundo tem ojeriza. Ia de táxi. O táxi esperava e, por mais incrível que pareça, a família, além de servir uma porção de coisas para ele - e ele recebia a consulta na hora! - , o chefe da família ou alguém ia até o motorista de táxi e pagava a viagem de ida e volta. Então, o médico era uma pessoa aureolada, muito diferenciada. Todos! Eram pessoas que tinham uma influência muito grande, mais que as outras profissões, inegavelmente! Alguns eram conselheiros de família. A pessoa ia ao consultório pedir opiniões para tomar decisões, até sobre casamento de filhos!

Nós estávamos em outro mundo! Tudo era diferente. Impressionante! Não há possibilidade de se imaginar o que era a vida naquela época. Era simples, tranqüila, a cidade era pequena, tudo muito limitado... Tenho a impressão de que as complicações eram muito menores. Vejam só: havia um único, não, dois prontossocorros em São Paulo: o Municipal, que era de assistência pública, e um pronto-socorro particular, o famoso 7-7777. Pertencia a um médico que fora amigo de meu pai, remador de um clube esportivo que existiu até há pouco tempo lá na beirada do Tietê, a Associação Atlética de São Paulo. Chamava-se dr. Mário Tobrini Costa, era um grande cirurgião, e sempre foi muito mal cotado no meio mais elevado, mais acadêmico. Faleceu há pouco tempo. Ele teve o lampejo de criar o primeiro pronto-socorro particular de São Paulo: Pronto-Socorro Santa Inês. Mas como era um sujeito muito arrojado, fazia coisas que, naquele ambiente meio provinciano, repercutiam malíssimo. Porque as pessoas eram muito empertigadas. A moral era muito diferente do que é hoje. Muito diferente! Ele anunciava até no rádio, o que era um escândalo! Tocava uma sirene, e aí vinha o anúncio: "7-7777! Pronto-Socorro 
"O curso de anatomia, que era dado em dois anos, passou a ser dado em tempo integral, em um ano.

Tínhamos anatomia das sete da manhã às dez horas da noite, todo dia, até sábado!”
Santa Inês." Olha, ele fazia uma propaganda bombástica. Imagine que a mãe tomava conta da portaria. E isso em 1940.

Quando comecei o curso de medicina, na nossa turma houve uma modificação célebre, uma reforma. Então, o curso de anatomia, que era dado em dois anos, passou a ser dado em tempo integral, em um ano. Tínhamos anatomia das sete da manhã às dez horas da noite, todo dia, até sábado! A anatomia era muito rigorosa, era uma verdadeira seleção. Tínhamos aula até meados de junho e, em seguida, havia uma prova parcial. Bem, para fazer essa prova, para poder entrar no exame escrito tínhamos que ter nota seis em prática. A anatomia era celebérrima nesse sentido. Fiz um exame considerado brilhante. Tirei dez no prático e dez no oral. Depois, acabei freqüentando o laboratório de anatomia, logo em seguida às festas de Natal, e fiquei monitor da disciplina. No fim do segundo ano, houve uma espécie de expurgo. Demitiram todos! Mandaram todo mundo embora! Consegui arrumar uma vaga no laboratório central do hospital, que dava atendimento a todos, tanto aos indigentes como aos pensionistas. Então comecei a aprender a colher sangue. Naquela época, fazia-se contagem de glóbulos picando a ponta do dedo. Colhia-se com a pipeta, preparavam-se as diluições e punha-se o material no microscópio. Requeria aprendizado que só vinha com o tempo. Fazia-se uma série de asneiras até aprender. Aos poucos, fui ficando especializado em executar provas de função renal, função hepática, padronizava, fazia novas técnicas. Recordo-me, por exemplo, que fui um dos primeiros, no Brasil, a fazer volume de sangue circulante, com corante chamado Azul de Evans, T-1822. Eu trabalhava em contato com o laboratório de hemodinâmica da Clínica Propedêutica, e aproveitava os cateterismos intracardíacos que estavam sendo iniciados na época - eu ajudava nisso, também - , aproveitava, puncionava a artéria femoral do paciente com uma agulha especial, injetava o contraste, depois colhia amostra arterial e media no fotocolorímetro. O mais sofisticado era o Coleman Júnior, que hoje é coisa de museu.

No quarto ano começamos o curso de clínica propedêutica médica. Nova reforma! O prof. Jairo Ramos conseguiu, experimentalmente, do Ministério da Educação, a licença para inaugurar o primeiro departamento numa escola de medicina do Brasil: o departamento de clínica médica. E aí constavam propedêutica, gastrenterologia, hematologia, pneumologia, cardiologia, endocrinologia, metabolismo e nutrição. Bom, a enfermaria era rigorosíssima! O professor ia a ela diariamente, e os assistentes tinham pavor dele! Nós, por tabela, também. Por exemplo: o doente internava, fosse a que horas fosse, tínhamos 24 horas para fazer o exame completo, uma anamnese completíssima com exame físico, que era corrigido pelo assistente. Recordo-me que, num domingo, 
eu estava no quinto ano, já era da enfermaria — um domingo de manhã, sol bonito, dia espetacular... Tinha entrado, na sexta-feira à noite, um paciente novo, e eu, no sábado de manhã, estava fazendo a evolução, quando o professor entrou. Era uma figura imponente, alta, muito elegantemente vestida. Entrou, pegou aquela papeleta, viu que não estava pronta, e perguntou quem era o assistente. Este tinha ido para Santos de ônibus, passar um fim de semana lá. O professor mandou localizá-lo, ficou sentado esperando ele voltar de Santos para confeccionar a anamnese do paciente que não tinha sido feita. Era desse rigor terrível! Brigava com todo mundo. Na enfermaria dele, aprendia-se violentamente! Aprendia-se muito...

Quando eu estava no quinto ano, comecei a me destacar na enfermaria de clínica e, sem falsa modéstia, era um dos melhores. E um dos assistentes, que hoje é professor em Campinas - prof. Sílvio dos Santos Carvalhal, na minha opinião um dos melhores médicos clínicos de propedêutica de São Paulo - convidou-me para trabalhar com ele, quando eu estava no sexto ano. Eu fazia o máximo para não ser reprovado por faltas. Nas aulas em que havia chamada obrigatória, ficava. Por exemplo, terapêutica clínica, no quinto ano. Aula teórica não era obrigado a assistir. Aula prática, assistia uma ou outra para constar presença. Obrigavam-nos a fazer um estágio noturno, durante um mês, no primeiro e segundo semestre, no prédio onde funcionou a Academia de Medicina de São Paulo.

Aliás, havia um conflito muito sério, porque a terapêutica clínica era clínica, também. Eles davam aula de clínica. Meu professor foi um senhor que exerceu a profissão até quase os noventa anos, autor de livros... Se não me engano, faleceu há pouco tempo. Era um especialista em gastrenterologia e dietética. Havia um conflito muito sério porque nós já tínhamos aprendido uma porção de coisas, inclusive na prática, no terceiro e quarto anos, e a terapêutica clínica era no quinto. Então já entrávamos não só com a formação de propedêutica, mas de clínica médica, inclusive de terapêutica. Ele dava arte de formular! Para nós, aquilo não entrava na cabeça. Fazer fórmula! Porque já tínhamos receitado o diurético, o digitálico, o remédio para úlcera, e ele vinha lá com a receitinha, tantos por cento de não sei o quê, mande dez... Era a arte de gormular. Ele levou meses naquilo, e havia certos conflitos...

Houve uma época na medicina, aqui, em que todos formulavam. Todos! Eu me recordo de farmácias pequenas, perto de minha casa, no tempo de moleque, lá na Bela Vista. Havia uma, chamada Ribeiro, que ficava entre o viaduto Major Quedinho e o atual viaduto Maria Paula. Uma casinha baixa, todas as casas iguais, como se fosse uma porta de mercearia. Eu me lembro que ia lá comprar remédio que o médico tinha aviado para minha avó: cápsulas, líquidos, xaropes... tudo era formulado. 
Aos poucos, foi-se infiltrando a medicação preparada. Quando me formei, já tínhamos, praticamente, tudo pronto. Claro que não havia nem comparação com o que se faz hoje. Por exemplo, só para lembrar a importância do diurético - eu sou da época do diurético mercurial —, ele era injetado! O diurético oral começou em 1955, sendo usado em hipertensão arterial, depois viu-se que tinha um efeito extraordinário em insuficiência cardíaca ou em qualquer tipo de edema.

Os professores exigiam muito cuidado no uso de medicação. Tinham pavor dos medicamentos! Recordo-me de um médico meio boêmio, formado uns quatro anos na minha frente, que estava no nosso grupo. Dizia que receitava sempre a mais porque não acreditava no que o laboratório prescrevia. Então dava sempre mais. Precisava ver o espanto no ambiente quando ele dizia uma coisa dessas. Nessa época, eu trabalhava no ambulatório da faculdade, muito modesto. Ficava num prédio ao lado: em cima era o Centro Acadêmico, embaixo, a sala de ambulatório. Nesse local, tinham as várias clínicas e então se usava a novidade: "Olha, chegou um remédio novo aí, assim, assim, assim..." A Rauwolfia, por exemplo, para hipertensão arterial. Recordo-me que comecei a usar lá, e me espantei de ver que a maioria dos doentes tinha um sono terrível. Dormiam com as doses que nós dávamos. Foi preciso aprender a utilizar essa medicação. Mas nós usávamos conscientes, e crentes de que precisava, que seriam úteis. Depois, vimos que muita coisa... não servia!

Em consultório comecei com o dr. Silvio Carvalhal. Ele era de família importante - os Carvalhais, aqueles que deram nome à rua. O pai, Tomás Carvalhal, tinha sido político pelo Partido Republicano Paulista, o PRP. E o sogro, seu correligionário, morava na avenida Paulista, um casarão enorme, alto, de dois andares, de onde se mudou. E o Silvio Carvalhal mudou o consultório para lá. Eu fui junto. O pai dele era muito amigo do Roberto Simonsen, era médico da empresa dele, a Cerâmica São Caetano. Ia três vezes por semana e ficava lá umas horas. Saía direto do Hospital São Paulo para São Caetano. Ele tinha um fusquinha alemão. Naquela época, poucos tinham carro. Eu pegava a minha malinha, tomava o bonde Avenida 3, descia na porta do consultório, entrava, e atendia os doentes que estavam lá, todos marcados. Examinava inteirinho, tirava a história, tal e tal, e deixava a pessoa lá. Quando ele chegava, relia a história, acrescentava, corrigia alguma coisa, reexaminava a pessoa, e eu lá, de olho. Ele receitava, e eu ouvia a orientação dele. Peguei muito a tarimba. Então passei a receber 20\% do que ele cobrava. A clínica era pequena porque ele não ligava muito.

Foi quando criaram um pronto-socorro na escola, com um plantão de laboratório clínico, de 24 horas por semana. Eu e outros acabamos ficando como plantonistas do pronto-socorro. 


\section{“Quando atendíamos, levávamos uma mala enorme, com tudo dentro. Levávamos oxigênio, eletrocardiógrafo e ali, a domicílio, resolvíamos o problema."}

Melhorei muito de vida porque passei a ganhar naquela época 4.300 por mês. Éramos sete para os sete dias da semana. Resolvemos fazer também um pronto-socorro, e fundamos o primeiro Pronto-Socorro de Cardiologia e Laboratório Clínico de São Paulo. Entramos com setenta mil cruzados cada, e deu para formar um pronto-socorro, com ambulância e raio X, inclusive. Foi o primeiro pronto-socorro especializado. Antes existiam prontos-socorros gerais. Na avenida Angélica ainda existe o ProntoSocorro Infantil Angélica, que foi o segundo pronto-socorro infantil da cidade. Houve um do prof. Nelson Gomes de Matos, na praça Oswaldo Cruz, em 1948, 1949.

O nosso foi de vento em popa! Atendíamos pessoas importantíssimas em São Paulo. A clínica do prof. Jairo Ramos, gente de tudo quanto era lugar. Ficamos cinco anos nesse pronto-socorro. Então larguei a clínica do dr. Silvio Carvalhal, e dava um plantão ou dois plantões de 24 horas. Ficamos lá de 1955 a 1960, quando o passamos adiante. Acabamos vendendo a sociedade para um médico goiano, que depois passou o pronto-socorro para uma equipe que continua lá, na Brigadeiro Luiz Antonio. É aquele pronto-socorro branco, enorme, Unidade Respiratória Cardiológica de São Paulo. Mas no começo não era só cardiologia. Aí é que está!

A idéia era fazer patologia. Nós tínhamos laboratório de emergência. Foi o primeiro a atender 24 horas por dia. Porque, como tínhamos o plantonista, e este era laboratorista, resolvíamos todos os problemas. Atendia-se cardiologia, clínica, tudo! Não fazíamos cirurgias nem internações. Só atendíamos a domicílio. Iase à casa do paciente, examinava-se e perguntava-se... Algumas vezes já sabíamos que o doutor fulano de tal tinha indicado. Então, imediatamente, se entrava em contato com ele e dizia: "Olha, seu paciente está com isso, isso e isso. O que o senhor quer que se faça? Já se fez isso. Quer que permaneça aqui, quer que remova?" Tratávamos um enfartado, por exemplo, no domicílio. Como tínhamos sete pessoas de plantão, fazíamos uma ficha completa, com toda a documentação, e ele era seguido diariamente. Cada dia ia um lá, examinava, tal e tal... Tínhamos um entrosamento muito bom, e todo paciente era muito bem atendido.

Quando atendíamos, levávamos uma mala enorme, com tudo dentro. Levávamos oxigênio, eletrocardiógrafo e ali, a domicílio, resolvíamos o problema. Agora, era muito cansativo. Tínhamos muito serviço. Era uma responsabilidade muito grande, e se arcava com ela sozinho. Eu adorava! Porque era minha característica. Eu não paro, faço muitas frentes. Mas o serviço não rendeu. E não rendeu porque era tudo cientista. $O$ pessoal tinha a cabeça na lua, não tinha experiência comercial. Levávamos cano como os diabos. Não se recebia. Precisava mandar cobrar. Era brutal! Depois de cinco anos de serviço, contabilizando tudo, consegui receber, 
"Sábado, eu tinha que atender cinco, seis, sete, oito doentes a domicílio. Hoje, chamado a domicílio é uma raridade! “ em parcelas, o suficiente para comprar um Dauphine. Nem um Volks pude comprar, porque era mais caro, e como o Dauphine tinha sido lançado há pouco...

Foi o primeiro carro que tive. Já era casado. Tinha uma filha, que hoje é doutora. Morava numa casinha de aluguel. Depois de cinco anos de atividade, não tinha nada! Tenho certeza absoluta - e isso eu dizia por meus companheiros - que nós tínhamos ali um filão, que aquilo era para evoluir para um pequeno hospital. Mas nem bem a sociedade começou a se estabilizar, um deles foi embora para os Estados Unidos; o outro, para Ribeirão Preto; outro estava sendo sondado para receber bolsa também. Então, fui desanimando. Falei: "Daqui a pouco vou ficar sozinho aqui. Então vou trabalhar sozinho para mim!" Foi o que decidi!

Em maio de 1960, montei consultório na rua Cincinato Braga, 102. Era uma casa velha. Entrei lá e encontrei uma série de companheiros. "Será que não tem uma vaga aî́? Eu estou precisando montar o consultório...", falei. Era um porão alto, bem arrumadinho, com uma sala de espera em comum com dois companheiros. Numa sala grande dividida em duas - sala de consulta e a de espera instalei o meu material, e não tive problemas porque o horário coincidiu com um outro emprego que eu precisei arrumar para me sustentar. Eu tinha uma série de companheiros que estavam pedindo emprego no IAPI, no serviço de perícia médica... "Olha!, eu também me interesso", falei. "Tá bom! Eles estão recrutando uma porção de gente lá." Então um deles conversou com o chefe e me disse: "Olha, você aparece na Várzea do Carmo, naquele conjunto de prédios do IAPI, perto da Mesbla..." Fiz um estágio de trinta dias. No fim, me aprovaram e me mandaram embora, para trabalhar no segundo período - tinham dois períodos de atividade no IAPI — lá no Tatuapé. Deixa eu ver, foi 1961, fevereiro de 1961. Começava às 15 horas e ia até às 18, no Tatuapé. Era uma viagem! Chegava ao consultório cinco e meia, seis horas. Felizmente não tinha clínica, tinha um ou outro clientinho, raro... Aos poucos é que foi começando.

A partir do segundo ano, o consultório começou uma lenta ascensão clínica, e passou a ter muitos clientes. Eu era chamado muito a domicílio. Minha filha era pequenininha, ia comigo no fim de semana. Eu examinava um monte de doentes. Ainda hoje pessoas ligam para minha casa e perguntam a minha mulher: "E a Glorinha, como é que vai?" "Mas como é que a senhora sabe?" "Ah, quando era pequena, ela ia lá em casa e tal..." Sábado, eu tinha que atender cinco, seis, sete, oito doentes a domicílio. Hoje, chamado a domicílio é uma raridade!

Minha clínica foi aumentando, lentamente, progressivamente... Nunca fiz propaganda, nunca pus anúncio no jornal, nem em revistinha. Foi crescendo, seguramente, por transmissão de alguém atendido por mim que gostou e indicou... Foi assim... As indicações 


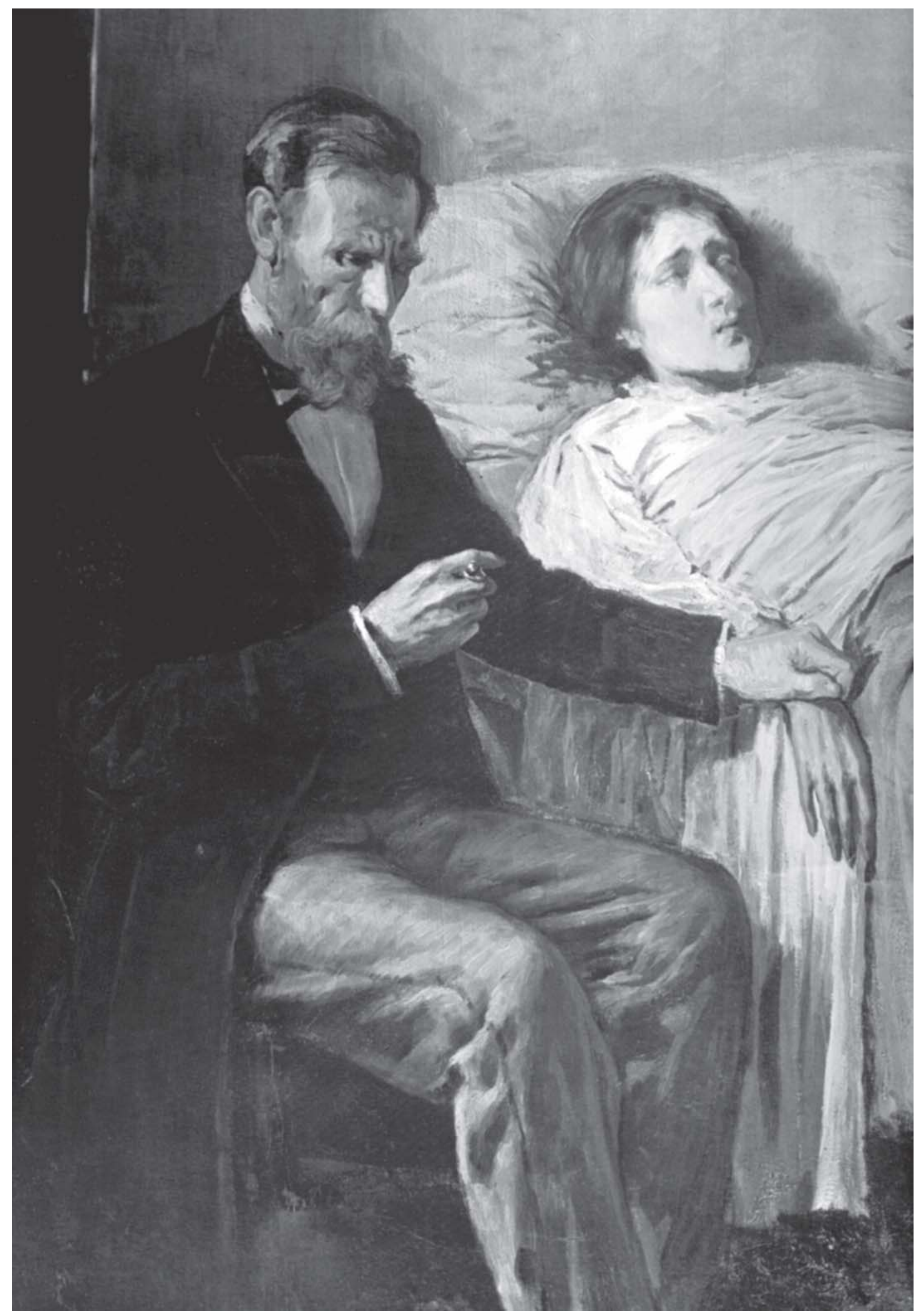


começaram, acredito, por colegas. Também sou credenciado do Banco do Brasil, atendo no consultório aos funcionários. Bem, o fato de ter começado junto com outros colegas, no mesmo prédio, isso ajudava a clínica. Alguns doentes eu recebi deles. É inegável.

Mas, também, eu me dedicava muito. Ainda hoje, modéstia à parte, sou escravo do doente. Me envolvo muito! Fico emocionalmente envolvido com a história do paciente. $\mathrm{O}$ indivíduo, no fim, acaba não sendo só meu cliente. Recentemente fui atender um. O cara estava passando malíssimo, botei no meu carro e fui para o Hospital das Clínicas, no Instituto do Coração! Então eu faço esse tipo de atendimento. Acho que não tem mérito nenhum, isso é o que devia ser o normal. Mas a pessoa fica agradecida, porque é um tipo de coisa que não existe mais. Eu faço.

Também a clínica no meu tempo era muito diferente. Não precisava de tanta coisa, nem se pedia tantos exames. Até hoje não peço. Quando fui para o meu consultório, já tinha um eletrocardiógrafo. Quando o pronto-socorro se desfez, um dos sócios na realidade, era uma espécie de orientador, um de nossos professores - tinha um aparelho de radioscopia. Ele não ia exercer mais a profissão, ia vendê-lo. Daí eu propus que me vendesse, pagando em determinadas circunstâncias; ele aceitou, eu comprei e levei para o consultório. Mais um materialzinho que eu tinha ali. Montei o consultório bem aparelhado já, razoavelmente aparelhado. Material esse que eu tenho até hoje, ainda em uso. Na época, isso representou uma coisa importante. Primeiro, porque eu manuseava aquilo ali. A radioscopia, por exemplo, já vinha estudando, conhecia muito bem, sem falsa modéstia. Depois comprei um aparelho de fundo de olho, por exemplo. Faço um exame rotineiro. Tenho dois aparelhos de audiometria. Então faço, rotineiramente, a determinação de oscilometria. Faço fundo de olho e radioscopia em todos os pacientes, e eletrocardiografia, eventualmente, em alguém que precise. Esses exames são importantes porque me facilitam enormemente. Eu prescindo de raio X de tórax, por exemplo, só peço em circunstância muito especial, quando tenho determinadas dúvidas.

Hoje já vou para exames até mais diferenciados: tomografia, por exemplo. Agora, pela experiência que adquiri em laboratório - trabalhei muitos anos -, eu, muito cedo, percebi que exame de laboratório não adianta nada. É o espírito do meu prof. Jairo Ramos... É muito difícil a gente traduzir em palavras o que ele era. Jairo Ramos tinha uma personalidade extraordinária. Foi um marco aqui em São Paulo. Lamento que não se tenha mais nada parecido. A presença dele como professor era marcante, diária. Ele agia com uma agressividade que era de importância fundamental na formação de quem passasse por ele. Exigia o exame do paciente antes de qualquer exame de laboratório. A pessoa 
“Hoje o médico não vai mais no domicílio, não pode, porque tem trezentas ocupações, duzentas atividades. Não vai! Esse é o grande defeito.” que fosse pedir exame devia justificar! O exame físico era detalhadíssimo. Quando se chegasse a um diagnóstico bem orientado, só então se complementava com alguma informação. Ainda hoje, só peço em circunstância muito especial. Minha rotina ainda está baseada no exame clínico.

Sou credenciado. Do Banco do Brasil atendo o maior número de pacientes, uns 15, 16 por mês. O resto é muitíssimo menos. Mesmo assim, apesar da facilidade para pedir exames, eu só o faço quando necessário. Aliás, é o contrário. Tem paciente que força uma série de exames para depois ver. Não adianta explicar: "Olha, o exame precisa ser feito em determinadas circunstâncias. O senhor não está sentindo nada, não precisa disso." "Não, eu quero dosar o colesterol! Eu quero ver o colesterol!"

Isto é muito difícil de vender para o paciente, mas, em todo caso, tento disciplinar. A maioria acaba compreendendo. A medicina mudou porque houve essa popularização da medicina em jornal, esse jornalismo barato, aí, de divulgação. Mas quando eu me defronto com pacientes que pedem exames de rotina e tal, tento convencer: só se for necessário!

Com a experiência que tenho, com o domínio que tenho sobre eles, consigo convencê-los. Eu ainda faço à moda antiga, à moda que aprendi. Converso longamente com o paciente, enfrento todos os problemas dele. Aqui no consultório, 80\% têm problemas de natureza outra, que não é médica. Então tem-se que sentir, captar, verificar quanto daquilo está influenciando no quadro que ele apresenta, na parte orgânica, real. E muito freqüentemente se verifica que não tem nada de orgânico, de importante. O que tem, realmente, são outros problemas, muito mais graves, de relacionamento familiar, econômico, social etc., que somatiza, vamos dizer assim. É preciso ter muita tarimba. Hoje, eu me considero um indivíduo tarimbado. E é esse o segredo da minha clínica. O pessoal gosta de minha ação, sem sombra de dúvida. Ah! eu vou até o fim com eles, vou ajudar, vou me imiscuir no problema, participar do problema. Eu me estraçalho com os doentes! Canso-me em demasia.

Ainda ontem atendi uma cardíaca descompensada, pela terceira vez, cardíaca grave. Nunca precisei interná-la. Ela vai voltar sextafeira para eu dar uma olhada e acertar a medicação. Tenho certeza absoluta de que ela vai dar uma equilibrada e pronto! Nunca forcei internação de doentes. Mais me chamavam a domicílio, mais eu assumia a responsabilidade. Achava que para eles era ótimo, porque gastavam menos. Sempre me coloquei muito nesse aspecto social, como os governos, que enfatizam muito, apesar de não fazerem nada pelo social. Eu fazia! Falava: "Esse cara vai gastar uma enormidade. Então deixa ver se eu..."

Hoje o médico não vai mais no domicílio, não pode, porque tem trezentas ocupações, duzentas atividades. Não vai! Esse é o 
grande defeito. Além da insegurança do pessoal novo, que não tem experiência de cuidar de doentes desse jeito. E tem outra: hoje ninguém mais tem tempo! A consulta, desde o início de minha prática, sempre foi muito demorada. Com doente novo, nunca menos de uma hora. Além disso, considero-me privilegiado porque ainda tenho uma memória muito boa. Então, conheço todos os doentes. Mas hoje tudo é diferente! Vejam a terapêutica, por exemplo. Bem, se compararmos a riqueza ou, pelo menos, a diversificação de hoje com a daquela época... tinha-se uma coisa muito limitada... e era até bom, porque se era obrigado a manusear muito menos coisas e se tinha, afinal, uma experiência maior. Hoje tem antibiótico, por exemplo, que eu nem sei usar! Nunca usei! Então a medicina sofreu uma modificação muito grande.

À medida que se envelhece, vai-se tendo experiência e vai se ficando descrente, o que é o pior! Porque o médico, com raras exceções, é um descrente! A não ser que tenha uma formação diferenciada, com uma linha, vamos dizer, de conduta filosófica, ou religiosa, ideológica... Mas, de maneira geral, o médico é um descrente. E eu estou entre esses. Pessimista, gozador na maioria das vezes; é isto que caracteriza a grande maioria. É que com a idade vamos cansando, não é mesmo? Vamos vendo que se luta ingloriamente, as coisas vão sempre piorando, ou, pelo menos, acha-se que pioram. Na realidade melhoram. Há essas modificações, a evolução... Hoje sabe-se muito mais, faz-se muito mais... Ah, não sei... não sei... Quando se é moço, se acha que a medicina vai fazer tudo, vai salvar, ajudar... Nós somos muito ingênuos! Vejam, ontem assisti a um programa na televisão em que o sujeito se dizia materialista. Que nada! Espera só ter uma dor de barriga. Sei não... Eu acredito em Deus, não sou materialista. Mas não consigo me conformar com a morte, com o sofrimento do paciente até a morte. Agora tem a Aids. A medicina ainda é muito frágil, não tem nada para fazer aí, mal conseguiu controlar as doenças infecciosas. Eu acho que ela ainda vai conseguir atuar, quando descobrir a etiologia... a medicina deverá melhorar as coisas. É... Mas também não vai adiantar muito, porque de alguma coisa sempre se morre...

\section{Ficha técnica}

Entrevistas: dr. Carlos e dra. Emília

Local: São Paulo

Datas: março-abril de 1988

Duração: 5:50h e 3:20h

Entrevistador: Lilia Blima Schraiber

Transcrição e $1^{\text {a }}$ edição: Carlos Augusto Luchesi

Conferência de fidelidade e $2^{a}$ edição: Lilia Blima Schraiber

Edição final: Jaime Benchimol e Ruth Martins 